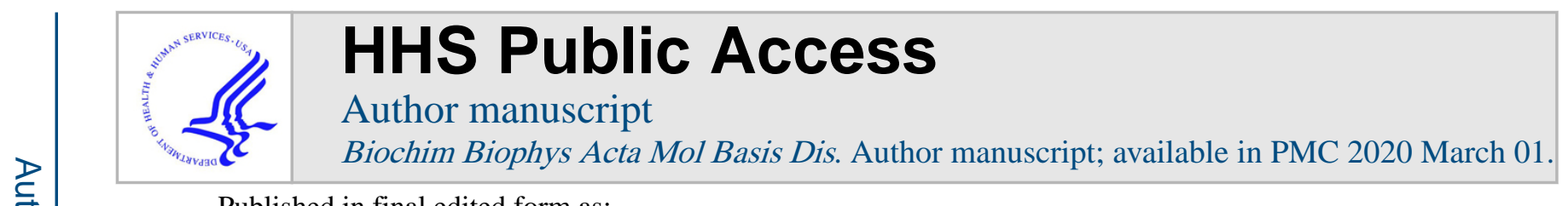

Published in final edited form as:

Biochim Biophys Acta Mol Basis Dis. 2019 March 01; 1865(3): 570-576. doi:10.1016/j.bbadis.

2018.12.012.

\title{
Sphk2-- mice are protected from obesity and insulin resistance
}

\author{
Shwetha Ravichandran ${ }^{\mathrm{a}}$, Brian S. Finlin ${ }^{\mathrm{b}}$, Philip A. Kern ${ }^{\mathrm{b}}$, and Sabire Özcan ${ }^{\mathrm{a},{ }^{*}}$ \\ aDepartment of Molecular and Cellular Biochemistry, Barnstable Brown Diabetes and Obesity \\ Center, College of Medicine, University of Kentucky, Lexington, Kentucky, United States of \\ America \\ bepartment of Medicine, Division of Endocrinology, Barnstable Brown Diabetes and Obesity \\ Center, College of Medicine, University of Kentucky, Lexington, Kentucky, United States of \\ America
}

\section{Abstract}

Sphingosine kinases phosphorylate sphingosine to sphingosine 1-phosphate (S1P), which functions as a signaling molecule. We have previously shown that sphingosine kinase 2 (Sphk2) is important for insulin secretion. To obtain a better understanding of the role of Sphk2 in glucose and lipid metabolism, we have characterized 20- and 52-week old Sphk $2^{-1-}$ mice using glucose and insulin tolerance tests and by analyzing metabolic gene expression in adipose tissue. A detailed metabolic characterization of these mice revealed that aging $S p h \mathrm{k}^{-/-}$mice are protected from metabolic decline and obesity compared to WT mice. Specifically, we found that 52-week male Sphk $2^{-1-}$ mice had decreased weight and fat mass, and increased glucose tolerance and insulin sensitivity compared to control mice. Indirect calorimetry studies demonstrated an increased energy expenditure and food intake in 52-week old male $S p h k 2^{-/-}$versus control mice. Furthermore, expression of adiponectin gene in adipose tissue was increased and the plasma levels of adiponectin elevated in aged Sphk $2^{-/-}$mice compared to WT. Analysis of lipid metabolic gene expression in adipose tissue showed increased expression of the Atglgene, which was associated with increased Atgl protein levels. Atgl encodes for the adipocyte triglyceride lipase, which catalyzes the rate-limiting step of lipolysis. In summary, these data suggest that mice lacking the $S p h k 2$ gene are protected from obesity and insulin resistance during aging. The beneficial metabolic effects observed in aged $S p h k 2^{-/-}$mice may be in part due to enhanced lipolysis by Atgl and increased levels of adiponectin, which has lipid- and glucose-lowering effects.

\footnotetext{
"Correspondence to: S. Özcan, Department of Molecular \& Cellular Biochemistry, University of Kentucky, College of Medicine, 741 S. Limestone St. BBSRB-155, Lexington, KY 40536, United States of America, sozcan@uky.edu.

Contribution statement

SR contributed to the acquisition and analysis of data and the revision of the article. SÖ contributed to the conception and design of the study, the acquisition, analysis and interpretation of the data and drafting of the article. BSF and PAK contributed to the analysis and interpretation of the data and the revision of the article.

Publisher's Disclaimer: This is a PDF file of an unedited manuscript that has been accepted for publication. As a service to our customers we are providing this early version of the manuscript. The manuscript will undergo copyediting, typesetting, and review of the resulting proof before it is published in its final citable form. Please note that during the production process errors may be discovered which could affect the content, and all legal disclaimers that apply to the journal pertain.

Conflict of Interest

The authors declare no conflict of interest.
} 


\section{Keywords}

sphingolipids; sphingosine kinase; obesity; diabetes; insulin resistance; Sphk2

\section{Introduction}

Sphingolipids are derived from ceramide, which is generated de novo from L-serine and palmitoyl-CoA catalyzed by serine palmitoyltransferases [1,2]. Ceramidases convert ceramide to sphingosine by hydrolyzing the fatty acids from ceramide. Sphingosine is then phosphorylated by two sphingosine kinases (Sphk1/2) to sphingosine 1-phosphate (S1P) [3]. Sphk1 has pro-survival activity, while $S p h k 2$ is pro-apoptotic [3-5]. They differ in their activity, regulation, and localization [3, 6]. Sphk1 and $S p h k 2$ null mice are viable, but deletion of both genes results in embryonic lethality [7]. While the function of $S p h k 1$ has been studied in detail in various tissues, the exact function of $S p h k 2$ remains to be determined [8]. A recent study suggests that polymorphisms in the $S p h k 2$ gene may contribute to the genetic predisposition to type 1 diabetes [9].

Sphingolipids, including ceramide and S1P serve as signaling molecules [10, 11]. S1P plays an important role in cell signaling, proliferation, cell survival and differentiation [11]. It has intracellular as well as extracellular signaling functions by serving as a ligand for five different $\mathrm{G}$ protein-coupled receptors $\left(\mathrm{S} \mathrm{P}_{1}-\mathrm{S}_{1} \mathrm{P}_{5}\right)[11,12]$. In mammals, there is a strong correlation between ceramide accumulation and age-related diseases, including type 2 diabetes, cardiovascular disease, cancer, and neurodegeneration [13-15]. While increased levels of ceramide are associated with insulin resistance in mice and humans, the role of S1P in regulation of glucose metabolism remains unclear [14, 16-19]. However, recent data suggest that increased levels of S1P are also associated with obesity and insulin resistance [20]. Plasma S1P levels have been shown to be elevated in both obese humans and rodents [21]. Furthermore, palmitate-induced increases in S1P levels have been associated with insulin resistance in pancreatic beta cells as well as in hepatocytes via activation of the S1P receptor subtype $2\left({\mathrm{~S} 1 \mathrm{P}_{2}}_{2}\right)[22,23]$. Administration of JTE-013, an $\mathrm{S}_{1} \mathrm{P}_{2}$ antagonist prevented the insulin resistance mediated by palmitate [20, 22, 23].

Adiponectin is mainly produced in adipocytes and has glucose- and lipid-lowering effects [24]. Recent studies suggest that the adiponectin receptors AdipoR 1/R2 have ceramidase activity and are capable of converting ceramide to sphingosine [25]. Binding of adiponectin to AdipoR1/R2 receptors stimulates their ceramidase activity, thereby leading to lowering of ceramide levels. Ablation of the adiponectin receptors in mice results in accumulation of ceramide, which is associated with insulin resistance and glucose intolerance [26]. These findings suggest that the beneficial pleiotropic effects of adiponectin on glucose and lipid metabolism are due to its ability to lower ceramide levels.

We have previously shown that $S p h k 2$ is important for insulin secretion from pancreatic beta cells [27]. A detailed characterization of $S p h k 2^{-1-}$ mice revealed that they are protected from age-related obesity and metabolic decline, which may be in part due to elevated adiponectin levels and enhanced lipolysis in adipose tissue of $S p h k 2^{--}$mice. 


\section{Materials and methods}

\subsection{Animals}

All animals were housed in a specific pathogen-free animal facility at the University of Kentucky on a 14-hour light and 10-hour dark cycle and kept under standard humidity and temperature conditions with free access to water and rodent chow. All animal procedures were reviewed and approved by the University of Kentucky Institutional Animal Care and Use Committee (Protocol 2011-0806). Sphk $2^{-/-}$mice on C57BL/6N background were obtained from the Jackson Laboratories (Stock No: 019140) and have been previously described in detail [7]. Sphk2 heterozygous mating pairs were used to generate $S p h k 2^{-/-}$and wild type litter mates. Animals were euthanized with carbon dioxide followed by cervical dislocation.

\subsection{Metabolic Tests}

All metabolic tests were carried out with male and female mice and followed the standard operating procedures as established previously [28]. The presented data were obtained with young mice (20-22 weeks of age) and old mice (50-54 weeks of age). For glucose tolerance tests (GTT), mice were fasted for 6 hours and i.p. injected with glucose $(2 \mathrm{~g} / \mathrm{kg})$. Mice were fasted for 4 hours before insulin tolerance tests (ITT) were carried out by i.p. administration of insulin $(0.75$ units $/ \mathrm{kg})$. In all tests, blood glucose was measured from tail vein at the indicated time points using the Nova Max Plus glucometer. Plasma insulin levels were measured using an insulin ELISA kit (Crystal Chem). Circulating levels of adiponectin and leptin were quantified using ELISA kits from Chrystal Chem. Triglyceride levels were measured using colorimetric kits from Abeam. Homeostasis model assessment of insulin resistance (HOMA-IR) was determined using the following formula: fasting glucose $(\mathrm{mg} / \mathrm{dL}) \times$ fasting insulin $(\mu \mathrm{U} / \mathrm{ml}) / 405$.

\subsection{Indirect Calorimetry and Body Composition Measurements}

Indirect calorimetry to monitor food consumption, physical activity, $\mathrm{O}_{2}$ consumption, and $\mathrm{CO}_{2}$ production was measured using the TSE LabMaster system by the COBRE Metabolic Core at the University of Kentucky. Fat and lean body mass was determined on conscious mice using an EchoMRI-5000 whole-body composition analyzer (Echo Medical System) that uses magnetic resonance relaxometry.

\subsection{Preparation of Protein Extracts and Western Blotting}

Isolated tissues were rapidly frozen in liquid nitrogen and stored in $-80^{\circ} \mathrm{C}$ until extract preparation. Total cellular extracts were prepared in lysis buffer (50mM Tris-HCI, pH 8.0, $20 \%$ glycerol, $140 \mathrm{mM} \mathrm{NaCI}, 1 \% \mathrm{NP}-40,1 \mathrm{mM}$ EDTA, $1 \mathrm{mM}$ DTT and protease/phosphatase inhibitors) using a tissue homogenizer. After incubation for $30 \mathrm{~min}$ at $4^{\circ} \mathrm{C}$, the lysates were centrifuged for $10 \mathrm{~min}$ at maximal speed and supernatants collected. Western blot analysis of whole cell lysates was conducted as previously described [29]. Sphk1 (sc-48825; rabbit polyclonal; dilution 1:1,000) and Sphk2 (sc-22704; goat polyclonal; 1:1,000) antibodies were from Santa Cruz Biotechnology, Inc and $\beta$-actin antibodies (A2228) were obtained from Sigma-Aldrich. CD36 (ab133625) and Atgl (\#2439) antibodies were from Abeam and 
Cell Signaling, respectively. Western blots were visualized using secondary antibodies conjugated to HRP in conjunction with ECL reagents (Thermo Scientific).

\subsection{Realtime (RT) PCR Analysis}

Total RNA was isolated using Trizol (Life Technologies) and $1 \mu \mathrm{g}$ of total RNA was used for cDNA synthesis with the qScript cDNA SuperMix kit (Quanta Biosciences). Quantitative RT-PCR (qRT-PCR) was performed on $\mathrm{M} \times 3005 \mathrm{P}$ real-time PCR instrument (Stratagene) using SYBR Green qPCR Master Mix (Applied Biosystems) as previously described [30]. All qRT-PCR data were normalized to $\beta$-actin mRNA levels. The genes and primers used for qRT-PCR quantification are listed in Table 1.

\subsection{Statistics}

Results are expressed as mean \pm SEM. For comparison between groups a two-tailed unpaired Student's $t$-test was used. A $p$ value of less than 0.05 was considered as statistically significant. Statistical analysis was performed using SPSS. $* p<0.05 ; * * p<0.01 ; * * * p^{<}$ 0.001 .

\section{Results}

\subsection{Sphk2 ${ }^{-/-}$mice have reduced weight and fat mass and are protected from age- dependent insulin resistance}

Aging is associated with weight gain and obesity. We measured the weight and fat mass of male $S p h k 2^{-1-}$ and WT mice at 20 and 52 weeks of age (Fig 1A). At 20 weeks of age, the weight of male $S p h k 2^{-1-}$ mice was about $10 \%$ less than of that of WT mice; however at 52weeks $S p h k 2^{-1-}$ mice displayed a 35\% decrease in body weight compared to WT (Fig 1A). In fact, the weight of 52-week old male $S p h k 2^{-1-}$ mice was similar to that of 20-week old mice. This suggests that while WT mice gained weight with age, the $S p h k 2^{-1-}$ mice maintained a fairly constant body weight. The reduction in body weight in $S p h k 2^{-/}$mice was first observed at 10 weeks of age (Fig S1A) and persisted in 77-week old male mice (Fig 1A). Echo-MRI analysis of lean and fat mass indicated a 36\% decrease in fat and an $8 \%$ increase in lean mass (normalized to \% BW) in male $S p h k 2^{-1-}$ versus WT mice at 20 weeks of age (Fig 1B \& S1B). At 52 weeks of age, the difference in fat and lean mass in Sphk $2^{-/-}$ versus WT was more pronounced with $85 \%$ decrease in fat and $22 \%$ increase in lean mass in male $S p h k 2^{-/-}$compared to WT mice (Fig 1B \& S1B).

During a glucose tolerance test (GTT), 52-week old male WT mice were unable to normalize blood glucose levels after glucose administration within a 2-hour time frame (Fig 1C). In contrast, blood glucose levels in male $S p h k 2^{-/-}$mice were almost back to normal within 2 hours. The area under the curve (AUC) for glucose was significantly lower for Sphk $2^{-/-}$versus WT mice (Fig 1C). Aged male $S p h k 2^{-1-}$ mice were also more insulin sensitive compared to WT (Fig 1D). Consistent with these findings, the HOMA-IR index for 52-week old male $S p h k 2^{--}$mice $(2.83 \pm 0.77)$ was significantly lower compared to WT mice $\left(11.38 \pm 1.37\right.$ ), confirming that $S p h k 2^{-/-}$mice are protected from insulin resistance during aging. There was no difference in glucose tolerance and insulin sensitivity in 20week old male WT versus $S p h k 2^{--}$mice (Fig S2A-B). 
The decrease in weight gain was also observed in female $S p h k 2^{-/-}$mice at the age of 22, 50 and 76 weeks, although it was not as pronounced as in male $S p h k 2^{-1-}$ mice (Fig 2A). While there was no significant difference in fat and lean mass in 22-week old female $S p h k 2^{-/-}$ mice, 50-week old female $S p h k 2^{-1-}$ mice had a $30 \%$ decrease in fat and $20 \%$ increase in lean mass compared to WT, when normalized to \% BW (Fig 2B). 50-week old female Sphk $2^{-1-}$ mice displayed improved glucose tolerance compared to WT (Fig 2C), however insulin sensitivity in female $S p h k 2^{-/-}$versus WT mice was not significantly different (Fig 2D). These data suggest that ablation of $S p h k 2$ in mice prevents age-related weight gain and obesity.

\subsection{Aged Sphk2 ${ }^{-/}$mice have lower fasting blood glucose levels and increased energy expenditure}

While random blood glucose levels between $S p h k 2^{-/-}$and WT mice at 20 and 52 weeks of age were similar, fasting blood glucose levels in 52-week old male $S p h k 2^{-1-}$ mice were significantly lower (35\% decrease) than in WT mice (Fig 3A). Moreover, 54-week old male WT mice showed signs of fatty liver compared to $S p h k 2^{-1-}$ mice after H\&E staining of paraffin-embedded liver sections (Fig 3B). There was no change in fasting blood glucose levels between male $S p h k 2^{-1-}$ and WT mice at 20 weeks of age (Fig 3A). Fasting blood glucose levels in 50-week old female $S p h k 2^{-1-}$ and WT were similar (Fig S2C). These data suggest that male $S p h k 2^{-/-}$mice are protected from age-dependent glucose intolerance and hepatic insulin resistance.

Metabolic studies using indirect calorimetry with 22- or 54-week old male $S p h k 2^{-/-}$and WT mice suggested that food intake (corrected for body weight) was significantly increased during the dark cycle in 22- and 54-week old $S p h k 2^{-/-}$mice (Fig 3C). The respiratory quotient was decreased during the light cycle in both 22- and 54-week old $S p h k 2^{-/-}$mice, while it was increased during the dark cycle in 54-week old Sphk $2^{-/-}$mice (Fig 3D). Although, total activity during the dark cycle was not significantly different between $S p h k 2^{-/-}$and WT mice, total activity during the light cycle was decreased in $S p h k 2^{-/-}$mice (Fig 3E). Energy expenditure (corrected for body weight) was increased during the light and dark cycle in both 22- and 54-week old male $S p h k 2^{-1-}$ versus WT mice (Fig 3F). Energy expenditure corrected for lean body mass was also increased in $S p h k 2^{-/-}$male mice (Fig S4A).

Female $S p h k 2^{-1-}$ mice displayed lower food intake during the light cycle, but higher food intake during the dark cycle (Fig. S3A). Respiratory quotient in female $S p h k 2^{-/-}$mice was decreased during light cycle similar to male $S p h k 2^{-1-}$ mice (Fig. S3B). In contrast to male mice, total activity in female $S p h k^{-/-}$mice was reduced by about $50 \%$ during the light cycle compared to WT (Fig S3C). However, there was no significant difference in energy expenditure in female $S p h k 2^{--}$versus WT mice when normalized for body weight (Fig. S3D). 


\subsection{Sphk2 ${ }^{-/-}$mice have increased expression and circulating levels of adiponectin during aging}

Aging $S p h k 2^{-1-}$ mice weigh less and have decreased fat mass compared to WT mice (Fig. 1), suggesting that they have altered lipid metabolism. Expression analysis of adipokines as well as lipid metabolic genes in gonadal white adipose tissue (WAT) indicated that the expression of adiponectin (2.6-fold), CD36 (3.5-fold) and Atgl(4.7-fold) genes were significantly upregulated in 54-week old male $S p h k 2^{-1-}$ versus WT mice (Fig 4A). However, there were no significant changes in expression of these genes in WAT of 22-week old Sphk $2^{-1-}$ versus WT mice (Fig. S4B). Consistent with the gene expression data, the levels of CD36 and Atgl protein were about 2-fold increased in WAT of $S p h k 2^{-/-}$mice compared to WT (Fig 4B-C). Atgl encodes for the adipocyte triglyceride lipase, which catalyzes the ratelimiting step in the hydrolysis of triglycerides [31,32]. Upregulation of Atgl suggests increased lipolysis in WAT of $S p h k 2^{-1-}$ mice. Increased expression of adiponectin in WAT of $S p h k 2^{-1-}$ mice correlated with increased plasma levels of adiponectin (Fig 4D). Adiponectin displays glucose- and lipid-lowering effects [24]. Thus, it is possible that $S p h k 2^{-/-}$mice are protected from age-dependent obesity and insulin resistance in part due to increased levels of adiponectin. Plasma leptin, triglyceride and insulin levels were significantly lower in aged male Sphk $2^{-/-}$versus WT mice (Fig 4D).

\section{Discussion}

Sphingolipids have been implicated in many diseases, including obesity and diabetes. Two important sphingolipids that function as signaling molecules are ceramide and S1P. Increases in ceramide levels are associated with insulin resistance [14, 33]. S1P has been shown to counteract ceramide function [11]. We report here that deletion of sphingosine kinase 2, which produces S1P, is beneficial and protects from metabolic decline during aging. Lack of $S p h k 2$ was associated with decreased weight and fat mass in both male and female mice, however the metabolic effects were more robust in male mice. Although aged female $S p h k 2^{-1-}$ mice weighed less than WT, displayed decreased fat mass and had significantly improved glucose tolerance, there was no significant difference in fasting blood glucose levels, insulin sensitivity and energy expenditure between aged female $S p h k 2^{-/-}$and WT mice.

Aging is associated with weight gain and obesity. Age-related changes in adipose tissue composition and function lead to insulin resistance and metabolic dysfunction [34, 35]. Male Sphk $2^{-1-}$ weighed about $35 \%$ less than WT mice and displayed an $85 \%$ reduction in fat mass at 52 weeks of age, suggesting that they are protected from age-related changes in adipose tissue function and composition. Sphk $2^{-/-}$male mice are more glucose tolerant and have lower fasting blood glucose levels during aging compared to WT. One of the hallmarks of insulin resistance is hyperinsulinemia that serves as a compensation mechanism. While aging WT mice were insulin resistant and displayed hyperinsulinemia, $S p h k 2^{-1-}$ mice had decreased plasma insulin levels and were protected from hyperinsulinemia. Interestingly, plasma insulin levels were reduced by about $40 \%$ even in 20-week old $S p h k 2^{-1-}$ mice (Fig S2D). This suggests that $S p h k 2^{-/-}$mice have chronically low levels of insulin, which is consistent with our previous observation that $S p h k 2$ is required for insulin secretion [27]. 
Caloric intake as well as energy expenditure was significantly increased in male $S p h k 2^{-/-}$ versus WT mice at 22- and 54-weeks of age. Despite the increased caloric intake, male Sphk $2^{-/-}$mice have decreased body weight and fat mass, which is likely to be attributed to increased energy expenditure. Interestingly, energy expenditure in 50-week old female Sphk $2^{-/-}$mice was not different from that of WT mice, suggesting the idea that the weight loss observed in aging female $S p h k 2^{-1-}$ mice is not due to increased energy expenditure. This indicates that $S p h k 2$ has different metabolic effects in male versus female mice.

Expression as well as circulating levels of adiponectin are increased $S p h \mathrm{k}^{-/-}$mice compared to WT. Thus, it is possible that the improved metabolic effects seen in Sphk $2^{-/-}$ mice could be in part due to increased adiponectin levels. Adiponectin is produced from the white adipose tissue and its expression is decreased during obesity. Adiponectin has lipidand glucoselowering effects and improves glucose metabolism [24]. Interestingly, there is a strong connection between adiponectin and ceramide levels. Adiponectin receptors AdipoR1 and AdipoR2 have been previously shown to function as ceramidases [25]. Thus, binding of adiponectin to its receptors decreases ceramide levels, which may be responsible for the lipid- and glucose-lowering effects of adiponectin. However, it is possible that the increased adiponectin levels in $S p h k 2^{-1-}$ mice may be due to decreased obesity in these mice. As reported previously, we confirmed that deletion of $S p h k 2$ leads to upregulation of plasma S1P by two-fold. Since S1P functions as a ligand for five different S1P receptors, increases in plasma S1P levels may lead to increased S1P signaling and thereby result in positive metabolic outcomes in Sphk2-/- mice.

Analysis of metabolic gene expression in WAT suggest that $S p h k 2^{-1-}$ mice have increased expression of Atgl encoding for the adipose triglyceride lipase, which catalyzes the ratelimiting step of lipolysis [36]. This indicates that $S p h k 2^{-1-}$ mice may be protected from obesity during aging in part due to increased lipolysis. The levels of the lipid transporter $C D 36$ were also significantly increased in WAT of $S p h k 2^{-1-}$ mice [31, 37], suggesting that lipid uptake into adipocytes of $S p h k 2$ null mice is increased. Since $S p h k 2$ is mainly localized to the nucleus, it is likely that is regulates the expression of lipid metabolic genes directly. Previous data suggest that Sphk2 and S1P interact with histone deacetylases HDAC1 and HDAC2 in the nucleus to inhibit their activity [38]. Consistent with the gene expression data, the levels of Atgl and CD36 protein were also increased about 2-fold in WAT of $S p h k 2^{-/-}$mice compared to WT. Since enzymes involved in the sphingolipid biosynthesis pathway have been shown to function as lipid sensors [39, 40], it is possible that Sphk2 has a similar function. Sphk2 could sense the rate of sphingolipid biosynthesis by binding to sphingosine. During increased flux, Sphk2 could mediate the suppression of processes that increase intracellular fatty acid levels, such as lipolysis (Atgl) and lipid uptake (CD36) during obesity. Loss of $S p h k 2$ would lead to increased lipolysis and lipid uptake. Consistent with the idea, recent findings suggest that inhibition of fatty acid synthase (Fasn) and thereby downregulation of fatty acid synthesis decreases the flux through the sphingolipid biosynthesis pathway in colorectal cancer cells [41].

In agreement with our findings, recently published data suggest that Sphk2 and/or S1P are associated with negative health outcomes. Sphk2 has been shown to promote kidney fibrosis via phosphorylation of Fyn to activate STAT3 and AKT, which could not be rescued by 
addition of extracellular S1P [42]. Increased S1P levels have been recently associated with type 2 diabetes and obesity [21,22]. Palmitate-induced increases in S1P levels in pancreatic beta cells have been demonstrated to antagonize insulin-stimulated cell growth and survival via activation of the $\mathrm{S} 1 \mathrm{P}$ receptor subtype $2\left(\mathrm{~S}_{1} \mathrm{P}_{2}\right)$. Administration of JTE-013, an $\mathrm{S}_{2} \mathrm{P}_{2}$ antagonist rescued the beta-cell damage attributed to the enhanced S1P-S1P 2 axis [22]. Similar data were also obtained in hepatocytes. An increase in hepatic S1P levels induced by palmitate caused insulin resistance via the $\mathrm{S} 1 \mathrm{P}-\mathrm{S}_{\mathrm{P}} \mathrm{P}_{2}$ axis, which could be reversed using the $\mathrm{S}_{1} \mathrm{P}_{2}$ antagonist JTE-013 [23].

Sphk1 and Sphk2 both produce S1P, but they differ in their regulation, tissue-distribution, and localization. There were no changes in Sphk1 expression and protein levels in livers of Sphk $2^{-1-}$ mice (Fig S4C-D), suggesting that there is no compensation by overexpression of Sphk1 in Sphk $2^{-1-}$ mice. This is in agreement with the original publication on Sphk $2^{-/-}$ mice, where it was reported that $S p h k 1$ expression was not altered in various tissue of $S p h k 2^{-1-}$ mice [7]. However, several reports indicate that inhibition of Sphk2 results in upregulation of $S p h k 1$ expression. It is possible that Sphk2 inhibitors increase Sphk1 levels by partially inhibiting Sphk1 activity. Although, there are no studies on Sphk1 function during aging, previously published data suggest that $S p h k 1$ null mice are protected from HFD-induced insulin resistance [43]. Interestingly, Sphk1 null mice on a HFD gain as much weight as WT mice, but display improved glucose tolerance and insulin sensitivity [43]. Since $S p h k 2^{-/-}$mice do not gain weight during aging, this suggests that Sphk1 and Sphk2 have overlapping as well as unique functions with respect to obesity and insulin resistance.

In conclusion, mice lacking $S p h k 2$ are protected from obesity and insulin resistance during aging. This indicates that increased Sphk2 levels or activity, and/or increased S1P levels during aging may contribute to obesity and metabolic dysfunction. Therefore, Sphk2 may be a potential drug target for treatment of age-related obesity and insulin resistance.

\section{Supplementary Material}

Refer to Web version on PubMed Central for supplementary material.

\section{Acknowledgements}

The authors thank Kara L. Larson for managing the initial Sphk $2^{-/-}$animal colony and Dr. Carole Moncman for help with microscopy. We also thank Drs. Lisa Cassis and Wendy Katz from the COBRE Metabolic Core at the University of Kentucky for their assistance with the Indirect Calorimetry studies and EchoMRI measurements.

Funding

This work was supported by AHA grant 14GRNT20380383 (to SO) and by Bridge Funding from the University of Kentucky (to SO). The COBRE Metabolic Core was supported by grants P20GM103527 and P20RR021954 from NIH.

\section{References}

[1]. Merrill AH, Jr., Sphingolipid and glycosphingolipid metabolic pathways in the era of sphingolipidomics, Chemical reviews, 111 (2011) 6387-6422. [PubMed: 21942574]

[2]. Tidhar R, Futerman AH, The complexity of sphingolipid biosynthesis in the endoplasmic reticulum, Biochimica et biophysica acta, 1833 (2013) 2511-2518. [PubMed: 23611790] 
[3]. Maceyka M, Sankala H, Hait NC, Le Stunff H, Liu H, Toman R, Collier C, Zhang M, Satin LS, Merrill AH, Jr., Milstien S, Spiegel S, SphK1 and SphK2, sphingosine kinase isoenzymes with opposing functions in sphingolipid metabolism, The Journal of biological chemistry, 280 (2005) 37118-37129. [PubMed: 16118219]

[4]. Igarashi N, Okada T, Hayashi S, Fujita T, Jahangeer S, Nakamura S, Sphingosine kinase 2 is a nuclear protein and inhibits DNA synthesis, The Journal of biological chemistry, 278 (2003) 46832-46839. [PubMed: 12954646]

[5]. Liu H, Toman RE, Goparaju SK, Maceyka M, Nava VE, Sankala H, Payne SG, Bektas M, Ishii I, Chun J, Milstien S, Spiegel S, Sphingosine kinase type 2 is a putative BH3-only protein that induces apoptosis, The Journal of biological chemistry, 278 (2003) 40330-40336. [PubMed: 12835323]

[6]. Pyne S, Lee SC, Long J, Pyne NJ, Role of sphingosine kinases and lipid phosphate phosphatases in regulating spatial sphingosine 1-phosphate signalling in health and disease, Cellular signalling, 21 (2009) 14-21. [PubMed: 18768158]

[7]. Mizugishi K, Yamashita T, Olivera A, Miller GF, Spiegel S, Praia RL, Essential role for sphingosine kinases in neural and vascular development, Molecular and cellular biology, 25 (2005) 11113-11121. [PubMed: 16314531]

[8]. Hatoum D, Haddadi N, Lin Y, Nassif NT, McGowan EM, Mammalian sphingosine kinase (SphK) isoenzymes and isoform expression: challenges for SphK as an oncotarget, Oncotarget, 8 (2017) 36898-36929. [PubMed: 28415564]

[9]. Holm LJ, Krogvold L, Hasselby JP, Kaur S, Claessens LA, Russell MA, Mathews CE, Hanssen KF, Morgan NG, Koeleman BPC, Roep BO, Gerling IC, Pociot F, Dahl-Jorgensen K, Buschard $\mathrm{K}$, Abnormal islet sphingolipid metabolism in type 1 diabetes, Diabetologia, 61 (2018) 1650 1661. [PubMed: 29671030]

[10]. Cowart LA, Sphingolipids: players in the pathology of metabolic disease, Trends in endocrinology and metabolism: TEM, 20 (2009) 34-42. [PubMed: 19008117]

[11]. Maceyka M, Harikumar KB, Milstien S, Spiegel S, Sphingosine-1-phosphate signaling and its role in disease, Trends in cell biology, 22 (2012) 50-60. [PubMed: 22001186]

[12]. Kihara Y, Maceyka M, Spiegel S, Chun J, Lysophospholipid receptor nomenclature review: IUPHAR Review 8, Br J Pharmacol, 171 (2014) 3575-3594. [PubMed: 24602016]

[13]. Sacket SJ, Chung HY, Okajima F, Im DS, Increase in sphingolipid catabolic enzyme activity during aging, Acta pharmacologica Sinica, 30 (2009) 1454-1461. [PubMed: 19749786]

[14]. Summers SA, Sphingolipids and insulin resistance: the five Ws, Current opinion in lipidology, 21 (2010) 128-135. [PubMed: 20216312]

[15]. Trayssac M, Hannun YA, Obeid LM, Role of sphingolipids in senescence: implication in aging and age-related diseases, The Journal of clinical investigation, 128 (2018) 2702-2712. [PubMed: 30108193]

[16]. Holland WL, Brozinick JT, Wang LP, Hawkins ED, Sargent KM, Liu Y, Narra K, Hoehn KL, Knotts TA, Siesky A, Nelson DH, Karathanasis SK, Fontenot GK, Birnbaum MJ, Summers SA, Inhibition of ceramide synthesis ameliorates glucocorticoid-, saturated-fat-, and obesity-induced insulin resistance, Cell Metab, 5 (2007) 167-179. [PubMed: 17339025]

[17]. Holland WL, Knotts TA, Chavez JA, Wang LP, Hoehn KL, Summers SA, Lipid mediators of insulin resistance, Nutrition reviews, 65 (2007) S39-46. [PubMed: 17605313]

[18]. Boden G, Ceramide: a contributor to insulin resistance or an innocent bystander?, Diabetologia, 51 (2008) 1095-1096. [PubMed: 18458870]

[19]. Zhao H, Przybylska M, Wu IH, Zhang J, Siegel C, Komarnitsky S, Yew NS, Cheng SH, Inhibiting glycosphingolipid synthesis improves glycemic control and insulin sensitivity in animal models of type 2 diabetes, Diabetes, 56 (2007) 1210-1218. [PubMed: 17470562]

[20]. Fayyaz S, Japtok L, Kleuser B, Divergent role of sphingosine 1-phosphate on insulin resistance, Cellular physiology and biochemistry : international journal of experimental cellular physiology, biochemistry, and pharmacology, 34 (2014) 134-147.

[21]. Kowalski GM, Carey AL, Selathurai A, Kingwell BA, Bruce CR, Plasma sphingosine-1phosphate is elevated in obesity, PloS one, 8 (2013) e72449. [PubMed: 24039766] 
[22]. Japtok L, Schmitz E.1., Fayyaz S, Kramer S, Hsu LJ, Kleuser B, Sphingosine 1-phosphate counteracts insulin signaling in pancreatic beta-cells via the sphingosine 1-phosphate receptor subtype 2, FASEB journal : official publication of the Federation of American Societies for Experimental Biology, 29 (2015) 3357-3369. [PubMed: 25911610]

[23]. Fayyaz S, Henkel J, Japtok L, Kramer S, Damm G, Seehofer D, Puschel GP, Kleuser B, Involvement of sphingosine 1-phosphate in palmitate-induced insulin resistance of hepatocytes via the S1P2 receptor subtype, Diabetologia, 57 (2014) 373-382. [PubMed: 24292566]

[24]. Xia JY, Morley TS, PE. Scherer, The adipokine/ceramide axis: key aspects of insulin sensitization, Biochimie, 96 (2014) 130-139. [PubMed: 23969158]

[25]. Holland WL, Miller RA, Wang ZV, Sun K, Barth BM, Bui HH, Davis KE, Bikman BT, Halberg N, Rutkowski JM, Wade MR, Tenorio VM, Kuo MS, Brozinick JT, Zhang BB, Birnbaum MJ, Summers SA, Scherer PE, Receptor-mediated activation of ceramidase activity initiates the pleiotropic actions of adiponectin, Nat Med, 17 (2011) 55-63. [PubMed: 21186369]

[26]. Yamauchi T, Nio Y, Maki T, Kobayashi M, Takazawa T, Iwabu M, Okada-lwabu M, Kawamoto S, Kubota N, Kubota T, Ito Y, Kamon J, Tsuchida A, Kumagai K, Kozono H, Hada Y, Ogata H, Tokuyama K, Tsunoda M, Ide T, Murakami K, Awazawa M, Takamoto I, Froguel P, Hara K, Tobe K, Nagai R, Ueki K, Kadowaki T, Targeted disruption of AdipoR1 and AdipoR2 causes abrogation of adiponectin binding and metabolic actions, Nat Med, 13 (2007) 332-339. [PubMed: 17268472]

[27]. Cantrell Stanford J, Morris AJ, Sunkara M, Popa GJ, Larson KL, Ozcan S, Sphingosine 1phosphate (S1P) regulates glucose-stimulated insulin secretion in pancreatic beta cells, The Journal of biological chemistry, 287 (2012) 13457-13464. [PubMed: 22389505]

[28]. Ayala JE, Samuel VT, Morton GJ, Obici S, Croniger CM, Shulman G.1., Wasserman DH, McGuinness OP, N.I.H.M.M.P.C. Consortium, Standard operating procedures for describing and performing metabolic tests of glucose homeostasis in mice, Disease models \& mechanisms, 3 (2010) 525-534. [PubMed: 20713647]

[29]. Vanderford NL, Andrali SS, Ozcan S, Glucose induces MafA expression in pancreatic beta cell lines via the hexosamine biosynthetic pathway, The Journal of biological chemistry, 282 (2007) 1577-1584. [PubMed: 17142462]

[30]. Mosley AL, Corbett JA, Ozcan S, Glucose regulation of insulin gene expression requires the recruitment of $\mathrm{p} 300$ by the beta-cell-specific transcription factor Pdx-1, Molecular endocrinology, 18 (2004) 2279-2290. [PubMed: 15166251]

[31]. Zimmermann R, Strauss JG, Haemmerle G, Schoiswohl G, Birner-Gruenberger R, Riederer M, Lass A, Neuberger G, Eisenhaber F, Hermetter A, Zechner R, Fat mobilization in adipose tissue is promoted by adipose triglyceride lipase, Science, 306 (2004) 1383-1386. [PubMed: 15550674]

[32]. Villena JA, Roy S, Sarkadi-Nagy E, Kim KH, Sul HS, Desnutrin, an adipocyte gene encoding a novel patatin domain-containing protein, is induced by fasting and glucocorticoids: ectopic expression of desnutrin increases triglyceride hydrolysis, The Journal of biological chemistry, 279 (2004) 47066-47075. [PubMed: 15337759]

[33]. Straczkowski M, Kowalska I, Baranowski M, Nikolajuk A, Otziomek E, Zabielski P, Adamska A, Blachnio A, Gorski J, Gorska M, Increased skeletal muscle ceramide level in men at risk of developing type 2 diabetes, Diabetologia, 50 (2007) 2366-2373. [PubMed: 17724577]

[34]. Guo SS, Zeller C, Chumlea WC, Siervogel RM, Aging, body composition, and lifestyle: the Fels Longitudinal Study, Am J Clin Nutr, 70 (1999) 405-411. [PubMed: 10479203]

[35]. Karakelides H, Irving BA, Short KR, O’Brien P, Nair KS, Age, obesity, and sex effects on insulin sensitivity and skeletal muscle mitochondrial function, Diabetes, 59 (2010) 89-97. [PubMed: 19833885]

[36]. Kim JY, Tillison K, Lee JH, Rearick DA, Smas CM, The adipose tissue triglyceride lipase ATGL/ PNPLA2 is downregulated by insulin and TNF-alpha in 3T3-L1 adipocytes and is a target for transactivation by PPARgamma, Am J Physiol Endocrinol Metab, 291 (2006) E115-127. [PubMed: 16705060]

[37]. Glatz JF, Luiken JJ, From fat to FAT (CD36/SR-B2): Understanding the regulation of cellular fatty acid uptake, Biochimie, 136 (2017) 21-26. [PubMed: 28013071] 
[38]. Hait NC, Allegood J, Maceyka M, Strub GM, Harikumar KB, Singh SK, Luo C, Marmorstein R, Kordula T, Milstien S, Spiegel S, Regulation of histone acetylation in the nucleus by sphingosine-1-phosphate, Science, 325 (2009) 1254-1257. [PubMed: 19729656]

[39]. Sociale M, Wulf AL, Breiden B, Klee K, Thielisch M, Eckardt F, Sellin J, Bulow MH, Lobbert S, Weinstock N, Voelzmann A, Schultze J, Sandhoff K, Bauer R, Ceramide Synthase Schlank Is a Transcriptional Regulator Adapting Gene Expression to Energy Requirements, Cell Rep, 22 (2018) 967-978. [PubMed: 29386138]

[40]. Chaurasia B, Holland WL, Summers SA, Does This Schlank Make Me Look Fat?, Trends in endocrinology and metabolism: TEM, 29 (2018) 597-599. [PubMed: 29685851]

[41]. Jafari N, Drury J, Morris AJ, Onono FO, Stevens PD, Gao T, Liu J, Wang C, Lee EY, Weiss HL, Evers BM, Zaytseva YY, De Novo Fatty Acid Synthesis-Driven Sphingolipid Metabolism Promotes Metastatic Potential of Colorectal Cancer, Mol Cancer Res, (2018).

[42]. Zhu X, Shi D, Cao K, Ru D, Ren J, Rao Z, Chen Y, You Q, Dai C, Liu L, Zhou H, Sphingosine kinase 2 cooperating with Fyn promotes kidney fibroblast activation and fibrosis via STAT3 and AKT, Biochim Biophys Acta Mol Basis Dis, 1864 (2018) 3824-3836. [PubMed: 30251698]

[43]. Wang J, Badeanlou L, Bielawski J, Ciaraldi TP, Samad F, Sphingosine kinase 1 regulates adipose proinflammatory responses and insulin resistance, Am J Physiol Endocrinol Metab, 306 (2014) E756-768. [PubMed: 24473437] 


\section{Highlights}

- Deletion of Sphk2 in mice protects from age-related obesity and insulin resistance

- $\quad$ Aged $S p h k 2^{-/-}$mice have decreased fat mass but increased lean mass

- $\quad S p h k 2^{-1-}$ mice display increased energy expenditure compared to WT

- $\quad$ Protection of $S p h k 2^{-1-}$ mice from obesity and insulin resistance may be in part due to enhanced lipolysis and increased adiponectin levels 

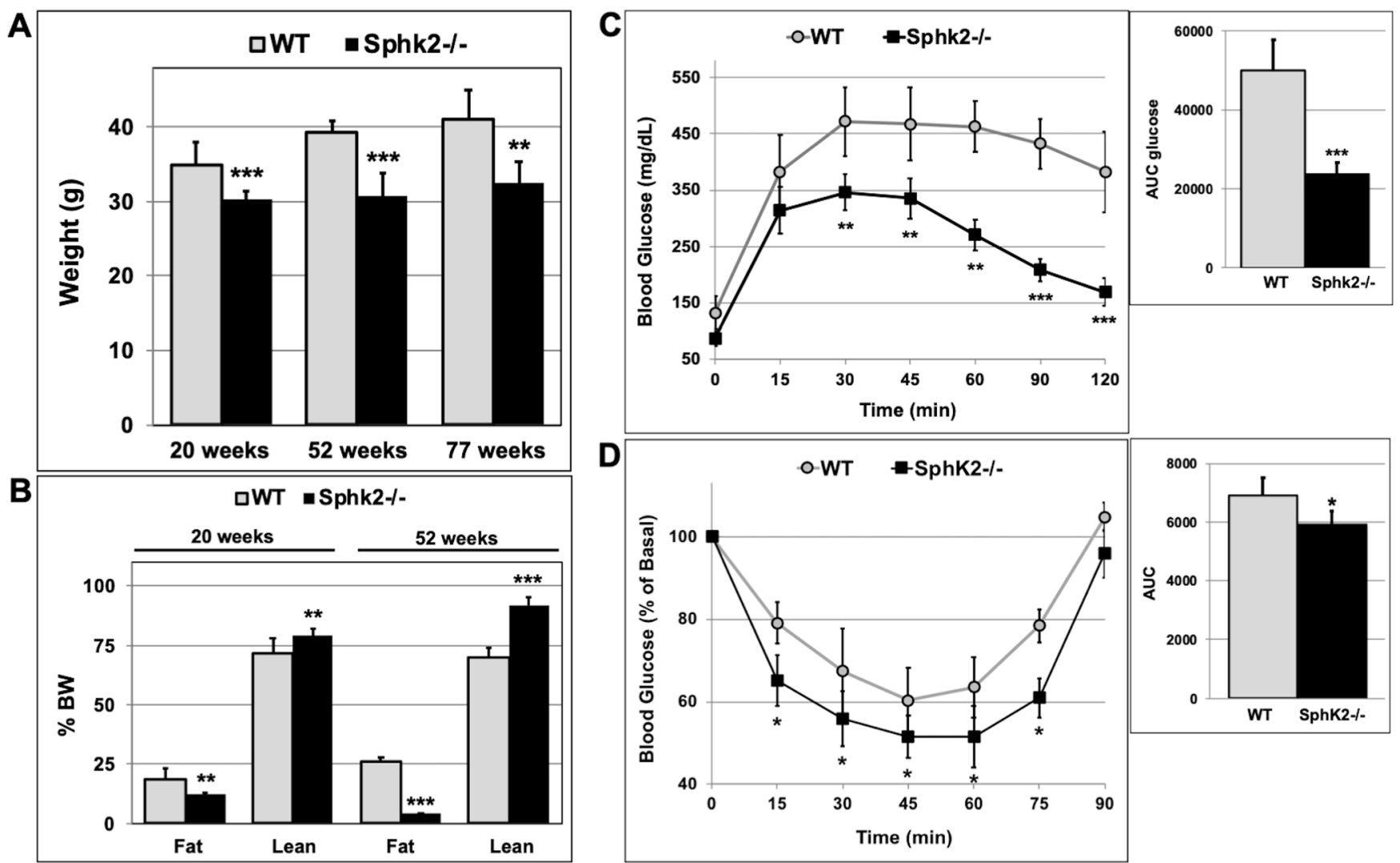

Fig 1. Male $S p h k 2^{-/-}$mice have reduced weight and fat mass and increased glucose tolerance and insulin sensitivity during aging.

(A) Weight of male WT and $S p h k^{-/-}$mice was measured at 20, 52, and 77 weeks of age $(\mathrm{n}=8-10)$. (B) Lean and fat mass in 20- and 52-week old male WT and $S p h k 2^{-1-}$ mice was measured using Echo-MRI (n=5-7). (C) GTT was performed in 52-week old male $S p h k 2^{-1-}$ and WT mice after a 6-hr fast; (n=5). (D) ITT was carried out in 54-week old male Sphk $2^{-1-}$ and WT mice after a 4-hr fast; $(\mathrm{n}=5) . * p<0.05 ; * * p<0.01 ; * * * p<0.001$. 

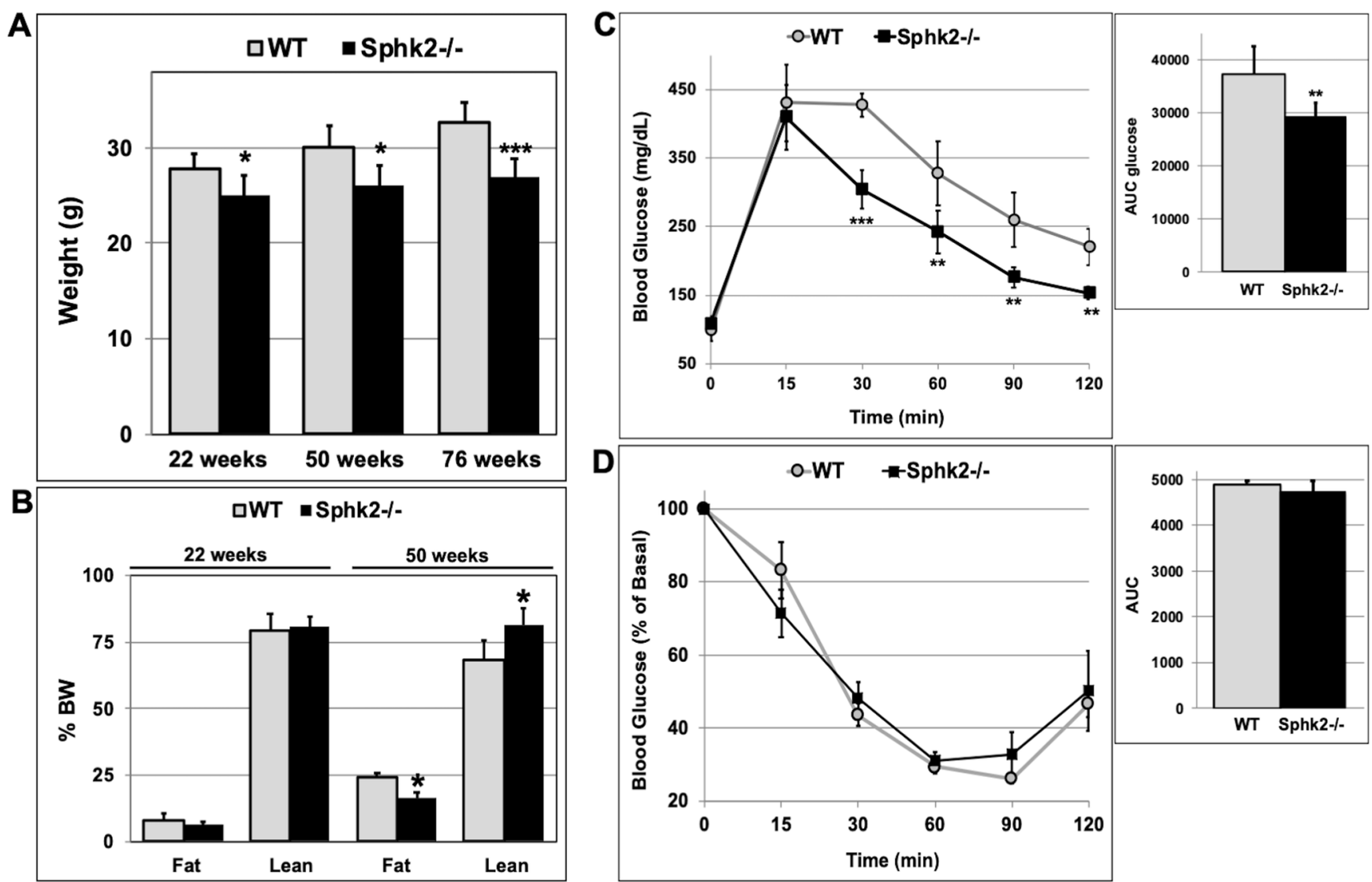

Fig 2. Female $S p h k 2^{-/-}$mice have decreased weight and fat mass, and increased glucose tolerance with aging.

(A) Weight of female $S p h k 2^{-/-}$and WT mice was measured at 22, 50, and 76 weeks of age $(\mathrm{n}=6-8)$. (B) Lean and fat mass in 22- and 50-week old female WT and Sphk $2^{-1-}$ mice was determined by Echo-MRI (n=5). (C) GTT and (D) ITT was performed in 50-week and 52week old female $S p h k 2^{-/-}$and WT mice, respectively $(\mathrm{n}=5) .{ }^{*} p<0.05 ; * * p<0.01 ; * * * p^{<}$ 0.001 . 

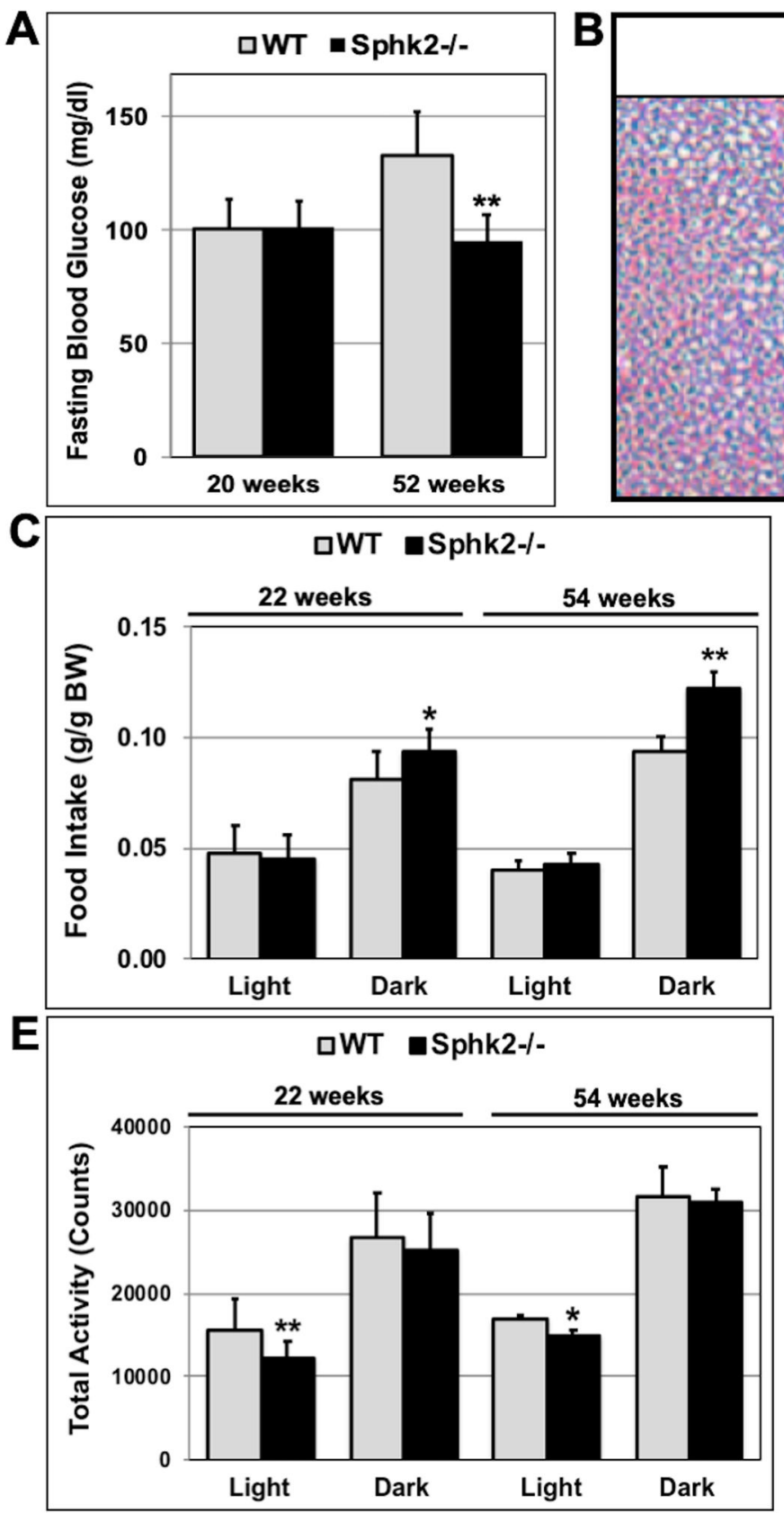

B
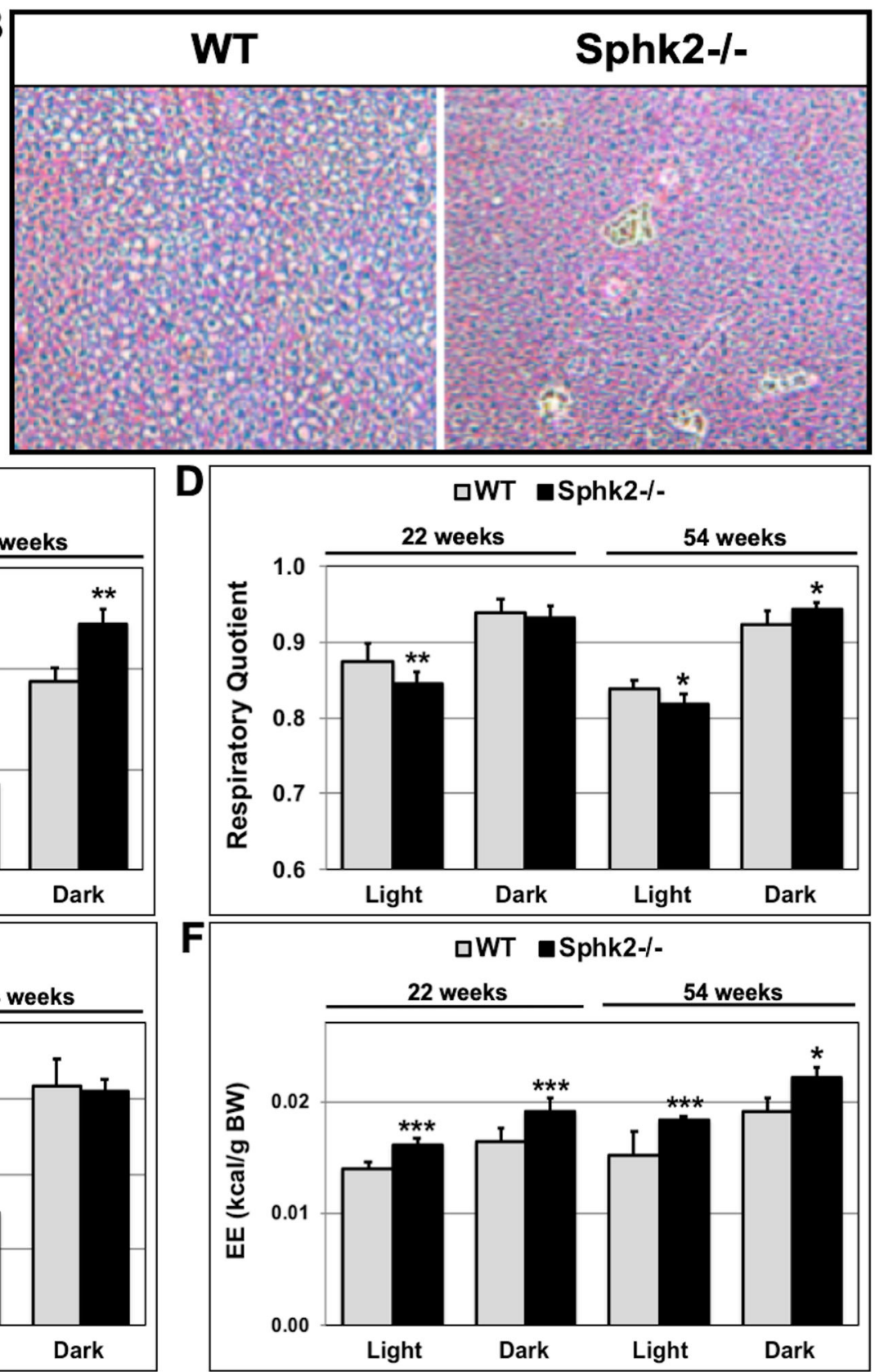

Fig 3. Male $S p h k 2^{-/-}$mice have lower fasting blood glucose levels and increased energy expenditure.

(A) Fasting blood glucose levels in 20- and 52-week old male $S p h k 2^{-/-}$and WT mice were measured after a $16 \mathrm{hr}$-fast $(\mathrm{n}=5)$. (B) Paraffin-embedded liver sections of 54-week old male $S p h k 2^{-/-}$and WT mice were stained with H \& E. Food intake (C), respiratory quotient (D), total activity $(\mathrm{E})$ and energy expenditure $(\mathrm{F})$ were determined using indirect calorimetry with 22- and 54-week old male mice $(n=8-10)$. Food Intake and energy expenditure were normalized for body weight. $* p<0.05 ; * * p<0.01 ; * * * p<0.001$. 


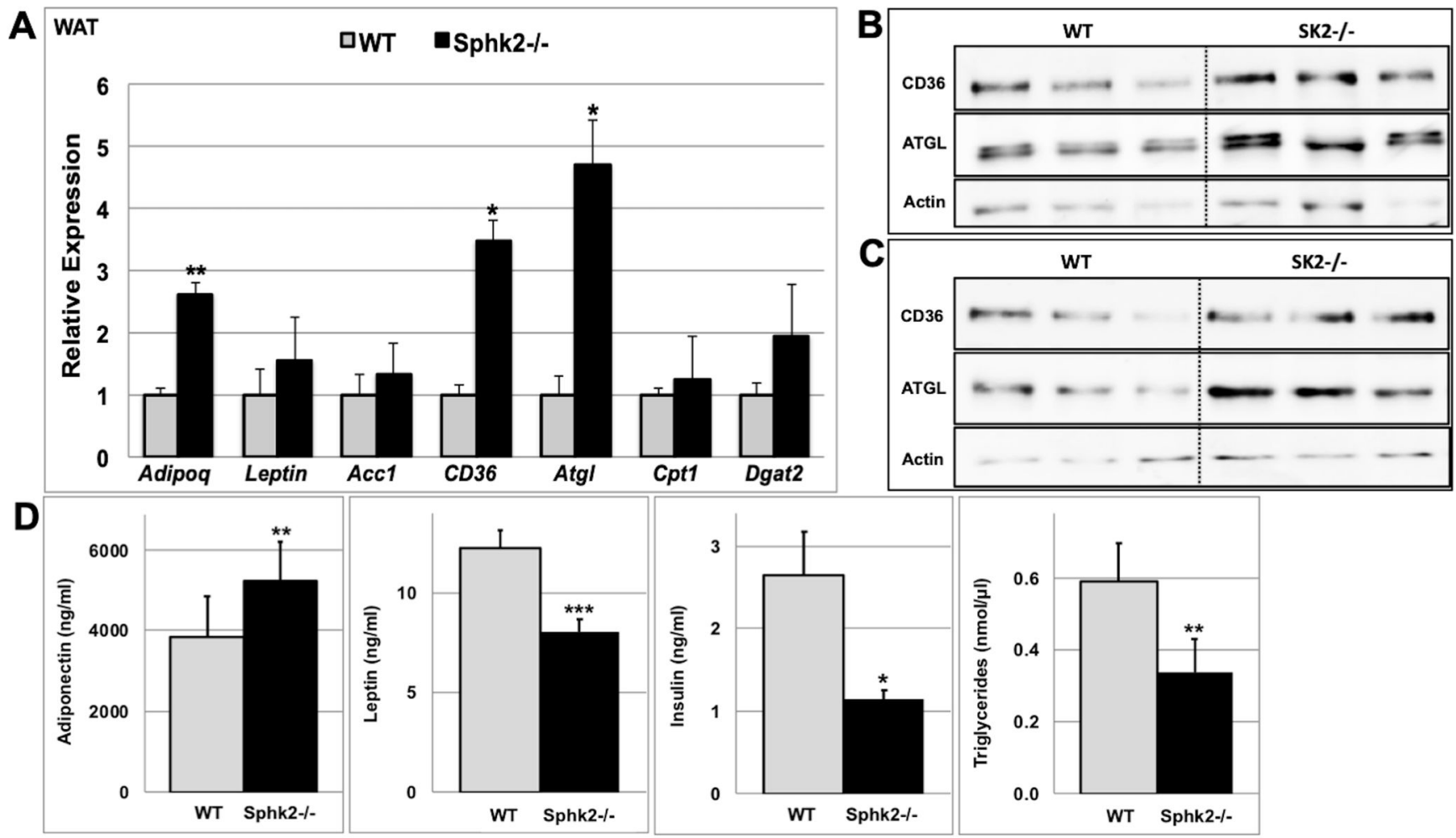

Fig 4. Aged male $S p h k 2^{-/-}$mice display increased expression and plasma levels of adiponectin. The expression of various adipokines ((Adipoq (adiponectin) and leptin)), lipid metabolic genes (Acc1 (acetyl CoA carboxylase), CD36, Atgl (adipocyte triglyceride lipase), Cpt1 (carnitine palmitoyl transferase I), and Dgat2 (diglyceride acyltransferase)) was quantified in WAT (A) of 54-week old Sphk $2^{-/-}$and WT male mice by qRT-PCR and normalized to betaactin levels $(\mathrm{n}=4)$. CD36 and Atgl protein levels were measured in WAT of 54-week old Sphk $2^{-/-}$and WT male mice under fed (B) or after $16 \mathrm{hr}$ fasting (C) conditions by immunoblotting with specific antibodies $(n=3)$. (C) Plasma adiponectin, leptin, insulin, and triglyceride levels were measured in 54-week old male $S p h k 2^{-/-}$and WT male mice using ELISA $(\mathrm{n}=5) . * p<0.05 ; * * p<0.01 ; * * * p<0.001$ 


\section{Table 1}

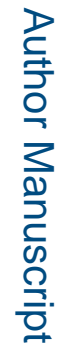

Sequences of primers used for RT-PCR

\begin{tabular}{|l|l|l|}
\hline Gene & Forward Primer & Reverse Primer \\
\hline Adipoq & GGAGAGAAAGGAGATGCAGGT & CTTTCCTGCCAGGGGTTC \\
\hline Leptin & AAGACCATTGTCACCAGGATC & GAAGCCCAGGAATGAAGTCC \\
\hline Acac & GGCCAGTGCTATGCTGAGAT & CCAGGTCGTTTGACATAATGGATG \\
\hline CD36 & TGAGACTGGGACCATTGGTGAT & CCCAAGTAAGGCCATCTCTACCAT \\
\hline Atgl & TGACCATCTGCCTTCCAGACT & TGTAGGTGGCGCAAGACAG \\
\hline Cpt1 & GCTGGGCTACTCAGAGGATG & CACTGTAGCCTGGTGGGTTT \\
\hline Dgat2 & AGGCCCTATTTGGCTACG TT & GATGCCTCCAGACATCAGGT \\
\hline Sphk1 & TCCTGGAGGAGGCAGAGATA & GCTACACAGGGGTTTCTGGA \\
\hline ActB & CGTGGGCCGCCCTAG & TTGGCCTTAGGGTTCAGGGG \\
\hline
\end{tabular}

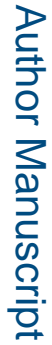

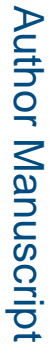

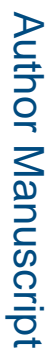

